\title{
膀脱内反性乳頭腫の臨床病理学的検討
}

\author{
一発生母地について一 \\ 自治医科大学泌尿器科学教室 \\ 小林裕 橋本 紳一 石川 真也 \\ 石山 俊次 徳江 章彦
}

\section{A CLINICO-PATHOLOGICAL STUDY OF INVERTED PAPILLOMA \\ OF THE URINARY BLADDER \\ Analysis of Histogenesis}

\author{
Yutaka Kobayashi, Shinichi Hashimoto, Shinya Ishikawa, Shunji Ishiyama and Akihiko Tokue \\ Department of Urology, Jichi Medical School \\ (Director: Prof. A. Tokue)
}

A clinico-pathological study was conducted on 9 cases with inverted papilloma of the urinary bladder.

1. Clinical study

The incidence of inverted papillomas, when compared with transitional cell carcinoma of the urinary bladder, was much higher in men than in women in our study and in the literlitured dealing with this subject as well.

Eight of 9 inverted papillomas were localized in the bladder neck. Cystoscopic examination revealed that all tumors were pedunculated and 8 of the 9 tumors had non-papillary surfaces.

These clinical findings suggest that inverted papillomas localized in the bladder neck are very similar to posterior urethral polyps with prostatic type epithelium.

Transurethral resection (TUR) was performed in all cases. Recurrence was not observed.

2. Pathological study

Inverted papillomas were classified into two types according to their histological patterns, determined by Hematoxylin-Eosin (H-E) staining. One pattern was glandular and the another was trabecular. Of the 9 cases, 2 were glandular, 5 were trabecular and the remaining 2 were a mixed type.

Immunohistochemical staining with anti-prostate specific antigen antibody revealed 3 of the 9 tumors were stained positively, and these tumors were classified a glandular type.

Inverted papilloma were classified into two patterns according to their histological patterns, determined by immunohistochemical staining with anti-keratin antibody, namely a bladder tumor pattern and a urethral tumor pattern. Inverted papillomas with a urethral tumor pattern were of the glandular type and included anti-PSA antibody positive staining tumors.

These findings suggest that a portion of inverted papillomas may have arisen from neoplastic transformation of prostatic tissue.

Key words: urinary bladder, inverted papilloma, histogenesis

要旨：病理組織学的に下部尿路の内反性乳頭腫と診断された 9 症例について臨床的ならびに病理組織学 的検討を行った。

1. 臨床的検討

性別では, 膀羘移行上皮腫瘍と比較して本研究においても文献的にも男性の頻度が圧倒的に高かった。 発生部位は, 膀胱頝部 6 時付近からが7/9症例に認められた。内視鏡的所見では非乳頭状 $8 / 9$ 症例, 乳頭 状が $1 / 9$ 症例に認められた。 またすべての症例が有茎性であった。この中の大部分をしめた非乳頭状の腫 
瘍の所見は前立腺上皮様尿道ポリープと類似していた。治療は経尿道的切除術を施行したが，不明の 2 例を除いて再発は認められなかった。

2. 病理組織学的検討

HE (hemotoxylin-eosin) 染色上，glandular type trabecular type に分類され，それぞれ2/9症例， $5 / 9$ 症例に認められ，また合併していたものは $2 / 9$ 症例であった。

抗 PSA (prostatic specific antigen) 抗体による免疫染色では3/9症例に陽性例が認められ，陽性例は すべて glandular typeを示していた。ささらに抗ケラチン抗体による染色パターンでは bladder tumor pattern と urethral tumor patternに分類され，urethral tumor patternを示した症例はHE染色上 glandular typeであり，また抗 PSA 抗体陽性症例もこの中に含まれていた.

これらの結果は内反性乳頭腫の発生母地の 1 つとして前立腺組織が考えられることを強く示唆してい た.

キーワード: 膀胱, 内反性乳頭腫, 発生母地

\section{緒言}

尿路における内反性乳頭腫は比較的稀な腫瘍であ

る.この組織学的特徴として

1）内反性の増殖.

2）表面を正常移行上皮が括扮うこと.

3）細胞異型が認められないこと.

4）小囊胞が認められることがあること.

5）時に扁平上皮化生を示すこと.

などが上げられ1), 良性の腫瘍と考学られている。し かしながら近年, 内反性乳頭腫の悪性変化を認めたと いら症例報告も散見される233)，さらに著者らは，本腫 瘍が前立腺尿道に発生した前立腺上皮様尿道ポリープ と内視鏡的に類似していることに着目している。そこ で内反性乳頭腫と, 異型度の低い移行上皮癌との関連 や，発生母地について関心がもたれるところである.

これらを明らかにするため, 内反性乳頭腫 9 例につい て臨床像を検討し, 同時に病理組織像について免疫組 織学的検討を行った。

\section{対象および方法}

自治医科大学付属病院泌尿器科において病理組織学 的に膀脱内反性乳頭腫と診断された 9 症例を対象とし た。

臨床的検討は年齢, 性別, 主訴, 血尿の有無, 発生 部位, 肉眼的形態, 大きさ, 治療法, 再発の有無につ いて検討した。

病理組織学的に検討は, 前立腺組織のマーカーであ る抗 PSA (Prostatic specific antigen) 抗体および抗 ケラチン抗体を用いて免疫染色を行いその染色性を検 討した.

すなわち

1) HE (Hematoxylin-Eosin) 染色にてKunze ら ${ }^{4)}$
の方法に従い glandular type, trabecular type に分類 した。

2). 前立腺藏器特異抗原にたいする抗体である抗 PSA 抗体，の染色性について検討した。

3）上皮細胞に広く分布するケラチンに対する抗ヶ ラチン抗体の染色性パターンについて検討した。

な拉，抗 PSA 抗体染色はPAP. (peroxidaseantiperoxidase）法，抗ヶラチソ抗体染色は $\mathrm{ABC}$ (Avidin-biotin peroxidase complex) 法で行った.

\section{結 果}

臨床的検討結果（表 1)

年齢は52歳から85歳で平均65歳であった。性別はす べて男性であった。主訴は肉眼的血尿 5 例, 排尿困難 1 例，頻尿 1 例，超音波検查で偶然に発見されたもの 2 例であった。

発生部位は膀胱頝部 8 例, 三角部 1 例であった。膀 脱䅡部に発生した 8 例中 7 例は 6 時方向より発生して いた。

腫瘍の内視鏡的形態は, 乳頭状 1 例, 非乳頭状 8 例 でこのらち 2 例は 1 部に乳頭状の形態を認めた。また これらすべてが有茎性であった，大きさは $2 \mathrm{~cm}$ 以下が ほとんどであり $2 \mathrm{~cm}$ 以上のものは 1 例のみであった。 治療はすべて経尿道的腫瘍切除術のみを施行した。

再発については 2 例がその後来院せず不明である が，他の 7 例では再発は認められなかった。

病理組織学的検討 (表 2)

HE 染色上, glandular type(図 1) 2 例, trabecular type(図 2 ) 6 例, 両者を合併しているもの 2 例であっ た。

免疫組織学的には抗 PSA 抗体陽性例 (図 3 ) が 3 例 に認められた。抗ケラチン抗体の染色では染色パター 
図 1 Glandular Type $(\mathrm{HE}, \times 40)$

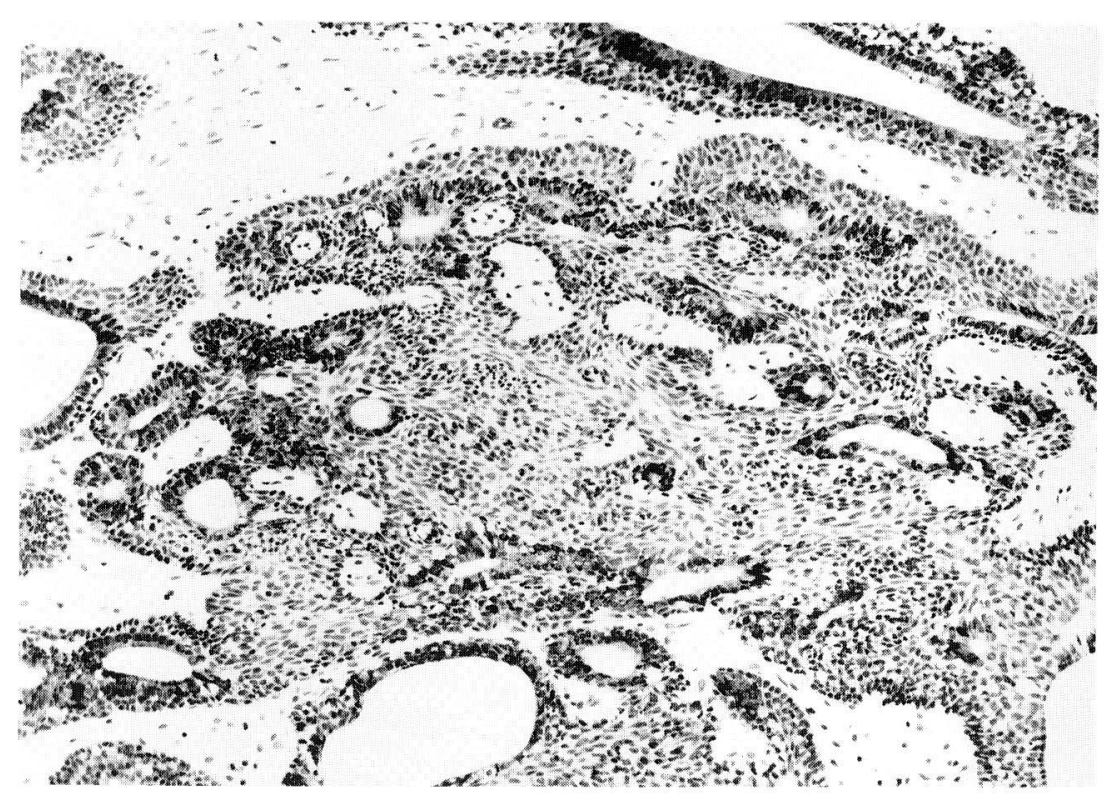

図 2 Trabecular Type $(\mathrm{HE}, \times 40)$

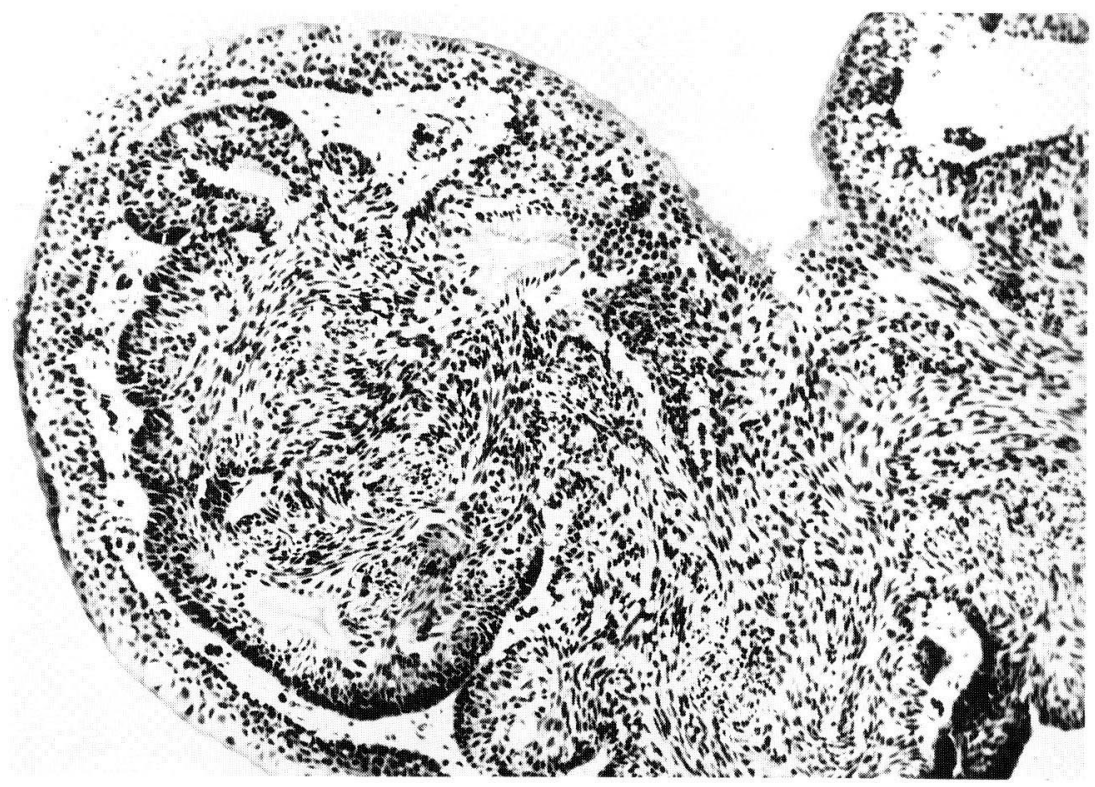

ンが移行上皮全体が一様に淡く染色されるものと腺管 様構造を示す上皮に強く染色されるものとに分類され た。前者を urethral tumor pattern（図 4 ）, 後者を bladder tumor pattern（図 5 ) としたが，それぞれ 5 例と 4 例であった。

これらの結果を総合すると, 抗 PSA 抗体の染色性
と $\mathrm{HE}$ 染色でのタイプとの関係では，抗 PSA 抗体陽 性例は HE 染色で glandular type を示す 4 例中 3 例 に認められた。

抗ケラチン抗体の染色パターンと HE染色のタイ プとの関係では glandular type は主に urethral tumor pattern を示していた.さらに抗 PSA 抗体の染 
図 3 抗 PSA 抗体染色陽性所見 $(\times 40)$

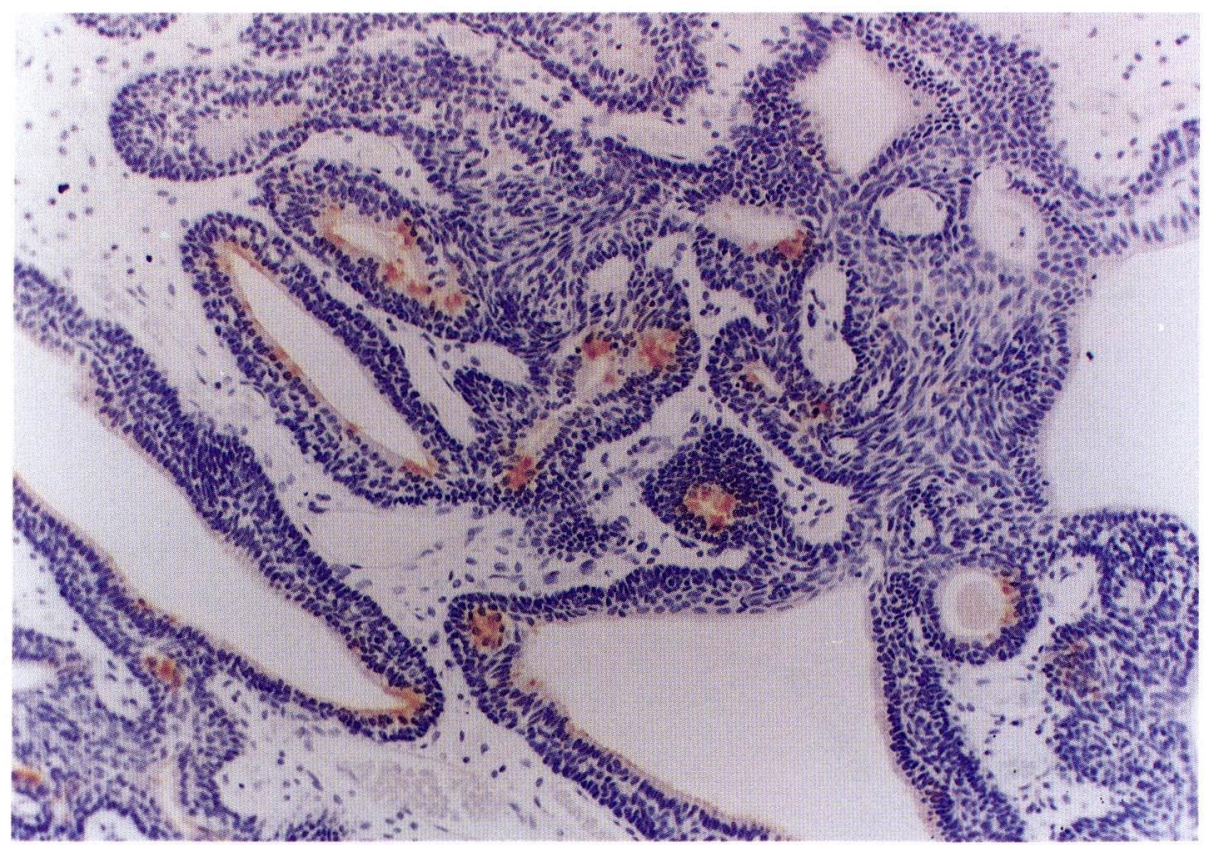

図 4 抗ヶラチン抗体染色 urethral tumor pattern $(\times 40)$

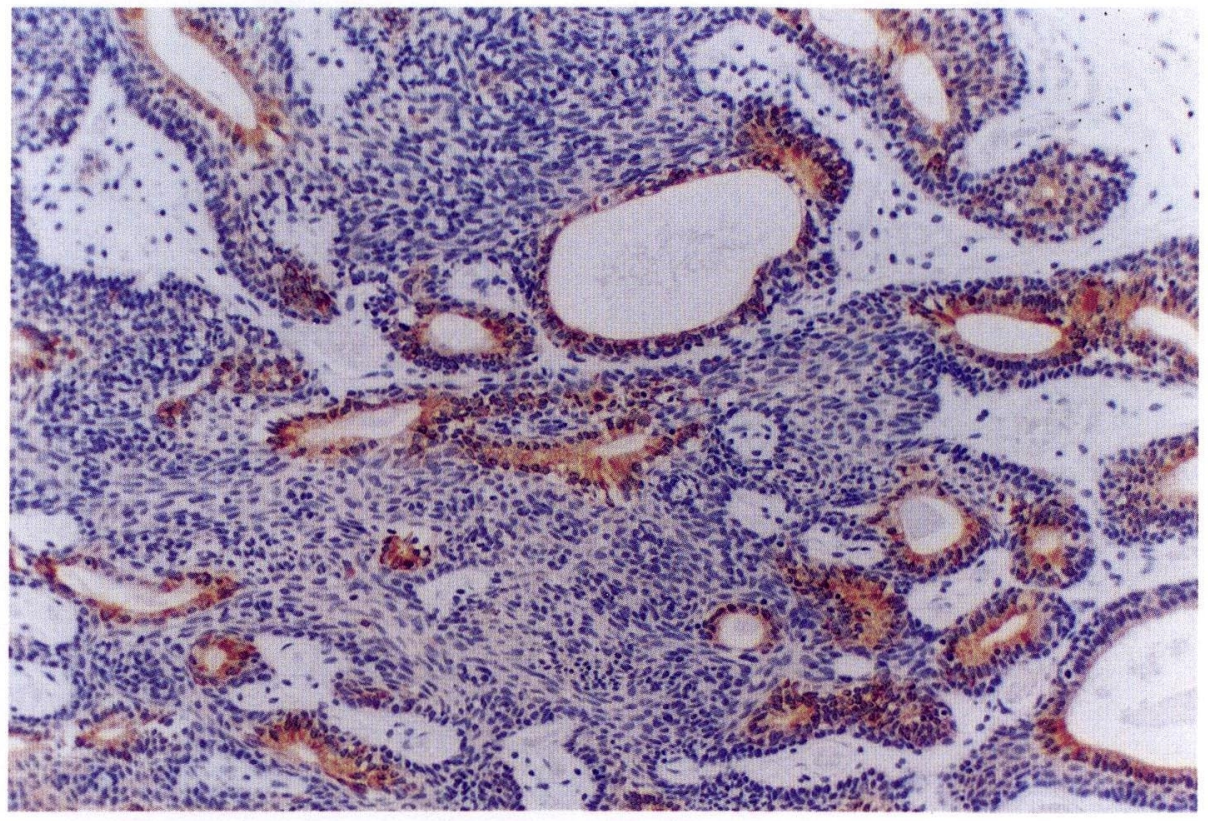

色性と抗ケラチン抗体の染色パターンとの関係では抗 PSA 抗体陽性例は urethral tumor pattern を示して いた。
すなわち, 抗 PSA 抗体陽性例は, HE 染色上 glandular typeのもののなかに認められ，また，これは抗 ケラチン抗体染色で前立腺腺管と同様の染色パターン 
図 5 抗ケラチン抗体染色 bladder tumor pattern $(\times 40)$

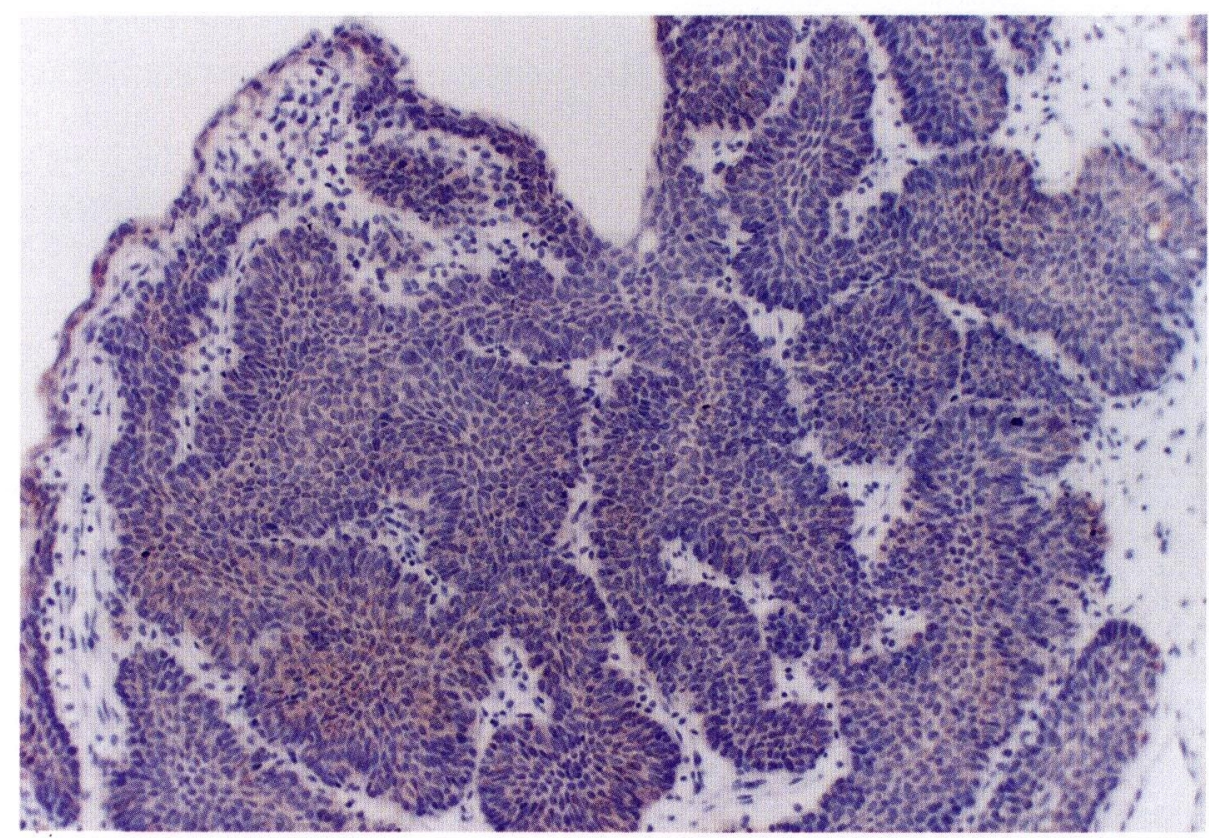

表 1 臨床所見

\begin{tabular}{|c|c|c|c|c|c|c|c|c|c|}
\hline No & 年,齢 & 性 & 主 訴 & 血尿 & 発生部位 & 大きさ $(\mathrm{cm})$ & 肉眼的形態 & 治療 & 再 発 \\
\hline 1 & 65 & 男 & - 血尿 & 有り & 膀胱頝部 ( 6 時～12時) & $2-3$ & 乳頭状 有茎性 & TUR & 不明 \\
\hline 2 & 52 & 男。 & 血尿 & 有り & 膀胼䅡部 ( 6 時 $８$ 時) & 1以下 & 非乳頭状 有茎性 & TUR & 無し( 3 年) \\
\hline 3 & 62 & 男 & 排尿困難 & 無し & 膀胱䅡部 ( 8 時) & $1-2$ & 一部乳頭状 有茎性 & TUR & 無し( 2 年) \\
\hline 4 & 57 & 男 & 血尿 & 有り & 膀胱䅡部 ( 6 時) & 1 & 一部乳頭状 有茎性 & TUR & 無し( $(2$ 年) \\
\hline 5 & 65 & 男 & 血尿 & 有り & 膀胱䅡部 ( 6 時) & 1 & 非乳頭状 有茎性 & TUR & 無し (6力月) \\
\hline 6 & 71 & ·男 & 頻尿 & 無し & 膀胱䅡部 ( 6 時) & 1 & 非乳頭状 有茎性 & TUR & 無し ( 3 カ月) \\
\hline 7 & 85 & 男 & 偶発 & 無し & 膀胼三角部 & $1-2$ & 乳頭状 有茎性 & TUR & 無し (6力月) \\
\hline 8 & 56. & 男 & 偶発 & 無し & 膀胱䅡部 ( 6 時) & 1 & 非乳頭状 有茎性 & TUR & 無し( 3 力月) \\
\hline 9 & 76 & 男 & 血尿 & 有り & 膀胱䅡部 ( 6 時 12時) & 1.5 & 非乳頭状 有茎性 & TUR & 不明 \\
\hline
\end{tabular}

を示す urethral tumor patternを示すものの中に認め られた。

\section{考察}

臨床的特徵について

性別は 9 症例すべてが男性であり，その平均年齢は 65歳であった。主訴は血尿が 5 例で約半数を占めてい た。 また超音波検査で偶然発見された症例が 2 例認め られたが，これは最近のスクリーニング検査の進歩が 伺觉る。さらに排尿障害に関係した症状を示した症例 も2 例認められたが, これは本症の発生部位が膀胱頝 部や前立腺部尿道に多いためと考学れれた。
自験例での発生部位はほとんどが膀羘䅡部 6 時方向 からであり，内視鏡的形態では有茎性で非乳頭状のも のが90\%を占めていた. kunze ら゙)が文献的に集計し た110症例の内反性乳頭腫の臨床的特徵でも, 男女比は 9:1 で圧倒的に男性に多く, 平均年齢は 57.3 歳で あった。発生部位では頝部 $44.7 \%$, 三角部 $36.8 \%$, 膀 脱前, 後壁, 側壁合わせて $11.4 \%$, 前立腺部尿道3.5\% であった。またこのうち女性に関しては，その発生部 位は, 頝部には少なく全体の $16 \%$ のであった。著者 らの症例では頝部に発生した腫瘍が90\%を占めていた が，これは著者らの経験した症例がすべて男性であっ 
表 2 組織学的所見

\begin{tabular}{c|c|c|c}
\hline No & $\begin{array}{c}\text { glandular (G)/ } \\
\text { trbecular (T) }\end{array}$ & 抗 PSA 抗体染色 & $\begin{array}{c}\text { 抗 keratin 抗体染色 } \\
\text { pattern }\end{array}$ \\
\hline 1 & G & + & urethral tumor \\
\hline 2 & G\&T & + & urethral tumor \\
\hline 3 & T & - & bladder tumor \\
\hline 4 & T & - & bladder tumor \\
\hline 5 & T & - & bladder tumor \\
\hline 6 & T & - & bladder tumor \\
\hline 7 & G & - & urethral tumor \\
\hline 8 & G\&T & + & urethral tumor \\
\hline 9 & T & - & bladder tumor \\
\hline
\end{tabular}

たためその頻度が高かったものと考兄られる。

以上より本腫瘍は通常の膀胱移行上皮癌と比較して 男性の発生頻度が高く，またその発生部位についても 従来前立腺組織が存在している膀脂䅡部や前立腺部尿 道からの発生頻度が高い傾向にあると思われた。

病理組織学的特徵について

内反性乳頭腫の発生原因については現在も十分な説 明は得られていない．Pott㧍よび Hirst ${ }^{5}$ はこの原因 を膀胱三角部下の腺管組織が内反性，有茎性に増殖発 生したものであると考察している。また，Caro と Tessler ${ }^{6}$ (は炎症の二次的な反応であると主張してい る。さらに Kunze ら ${ }^{4}$ はこの組織発生を 2 つに分類し trabecular type は basal cell の増殖により発生し, glandular type は, Brunns' nest $の$ 形成が cystitis cystica となりさらに cystitis glandularis,ついには腫 瘍性増殖を生じたものであると述べている。また一方 Renfer ら》は膀脱内反性乳頭腫に対してわれわれと同 様の免疫組織学的検討を行い前立腺腺管からの発生可 能性を示している。

著者らは, 以前数例の腺腫様尿道ポリープを経験し, このらちいくつかが内視鏡的に膀胱䅡部に発生した内 反性乳頭腫と酷似していることに着目した。一般に腺 腫様尿道ポリープの組織学的特徵として，その表面は 移行上皮ないし扁平な円柱上皮によりお打われ，ポ リープの頝部は乳頭状で前立腺由来上皮に酷似してい る.さらに特徵ある所見として，種々の大きさを呈す る前立腺小葉を認めることである。すなわちこの前立 腺由来の上皮は抗 PSA 抗体などの前立腺組織のマー カーにより染色される。

さらに文献的にその発生部位は，多くが前立腺部尿
道 6 時方向である ${ }^{819)}$.

そこで，著者らは内反性乳頭腫の発生母地が前立腺 上皮様尿道ポリープと同様に前立腺腺管である可能性 を免疫組織学的に検討した，この結果，形態的には尿 道腺腫様ポリープと内反性乳頭腫とは異なっていたも のの一部の内反性乳頭腫が前立腺組織のマーカーであ る抗 PSA 抗体で染色された。

またケラチンは，上皮組織に広く分布している，膀 脱移行上皮腫瘍での抗ケラチン抗体染色では移行上皮 が一様に淡く染色され，一方前立腺組織では腺管上皮 細胞に強く染色される7), これらの染色パターンは内 反性乳頭腫でも観察され, HE 染色上 glandular type のものは prostatic tumor pattern, trabecular type $の$ ものは bladder tumor patternを示していた。

さらに前立腺組織のマーカーで染色されたものは, prostatic tumor pattern を示し，またその発生部位は すべて前立腺組織の存在する膀胱䅡部 6 時方向であっ た.

これらを総合して考兵ると, 前立腺上皮が何かの原 因で移行上皮様に内反し，増殖した場合前立腺組織の マーカーにより染色される内反性乳頭腫が形成される 可能性が示唆される。すなわち男性に和ける内反性乳 頭腫の場合 brunns's nest cell, や basal cell 由来以外 の内反性乳頭腫の存在が示唆された.

\section{結語}

9 例の内反性乳頭腫の臨床的ならびに病理組織学的 検討を行い，以下のような結果を得た。

1）臨床的特徵として本症は男性に圧倒的に多く認 められた。 またその発生部位は膀胼頝部 6 時方向に頻 度が高かった。これらの発生部位は, 前立腺上皮様尿 道ポリープの発生部位と類似していた。

2) 病理組織学的特徵として, 前立腺組織固有のマ一 カーである抗 PSA 抗体により染色された腫瘍が $3 / 9$ に認められた。また，これらはすべて前立腺腺管が存 在する膀胱䅡部より発生した腫瘍であった。

3）以上により, 発生母地が前立腺組織である内反性 乳頭腫の存在の可能性が強く示唆された。

な抢本論文の要旨は第56回日本泌尿器科学会東部総会に 扔いて発表した。

\section{文 献}

1) Henderson, D.W., Allen, P.W. and Bourne, A.J. : Inverted urianry papilloma. Report of five cases and review of the literature. Virchows Arch. (Pathol. Anat.), 336, 177-186, 1975. 
2) 永井信夫, 井口正典, 秋山隆弘, 花井淳: Dysplastic inverted papilloma の 1 例. 一その臨 床的対処について一. 泌尿紀要, 25, 1055-1060, 1979 .

3) Lazarevic, B. and Garret, R. : Inverted papilloma and papillary transitional cell carcinoma of uriary bladder. Report of four cases of inverted papilloma, one showing papillary malignant transformation and review of the literature. Cancer, 42, 1904-1911, 1978.

4) Kunze, E., Shauer, A. and Schmitt, M. : Histology and histogenesis of two different types of inverted urothelial papillomas. Cancer, 51, 348-358, 1983.

5) Potts, I.F. and Hisrst, E. : Inverted papilloma of the bladder. J. Urol., 90, 175, 1963.
6) Caro, D.J. and Tessler, A.: Inverted papilloma of the bladder: A distinct urological lesion. Cancer, 42, 708, 1978.

7) Renfer, L.G., Kelley, J. and Belville, W.D. : Inverted papilloma of the urianry tract: Histogenesis, recurrence and associated malignancy. J. Urol., 140, 832-834, 1988.

8）小村隆洋, 吉田利彦, 森本鎮義, 新家俊明, 大川順 正：前立腺部尿道に発生した乳頭状腺腫 (adenomatous polyp with prostatic type epithelium)の 2 例. 泌尿紀要, 33, 1132-1137, 1987.

9）恒本 滋, 久保田茂弘, 白石和孝, 近藤 厚, 岸川 正大：前立腺上皮からなる後部尿道ポリープの 1 例. 西日泌尿，51，951-954， 1989.

（1992年 7 月 16 日受理） 